\title{
Evaluation of Policy for Admission of New Students through Independent Examination in North Sumatra University Uses Stake's Countenance Model
}

\author{
Suandi Silalahi ${ }^{1}$, Sugiarto ${ }^{2}$, Nurhattati ${ }^{3}$ \\ \{suandisilalahi22@gmail.com ${ }^{1}$, sugiarto63sutomo@gmail.com², nurhatatti@gmail.com ${ }^{3}$ \} \\ Universitas Negeri Jakarta, Indonesia
}

\begin{abstract}
This study aims to describe comprehensively the evaluation of the policy for admission of new students through an independent examination at the University of North Sumtera (UMBPT-USU). This evaluation study uses Stake's Countenence Model. Data collection techniques using analysis of literature studies, secondary data documents, observation, and indepth interviews that support validity analysis. The results of this study illustrate: (1) the antecedents phase process (formulation of policy making), (2) the transaction phase (planning, implementing, organizing, and supervising policies (3) outcome phase of the results of the implementation of the independent exam in receiving new students at the University of North Sumatra.In accordance with Stake's model, this paper describes two principal ways of proccesing descreptive evaluation data, the contingencies among antecedents, transactions and outcomes and finding the congruence between intens and observations of each phase and judgment made by the evaluator based on certain standard criteria.This evaluation is expected to provide results that can be one of the references in the new student admission policy at state university (PTN).
\end{abstract}

Keywords: Evaluation, policy implementation, new student admission, antecedents, transactions, outcomes, contingency, congruence, UMBPT-USU, PTN.

\section{Introduction}

The role of higher education is very important in advancing the life of the nation and state in various fields. Countries that have strong influence in the world are countries that have a history of developing good tertiary education. Kerr in The Uses of the University said that each nation, as it has become influential, has been developed to develop the leading intellectual of its world. Therefore, almost all countries pay enormous attention to manage higher education in their respective countries.

Managing higher education includes the entire process from the admission of new students, the provision of facilities and infrastructure, curriculum and lecturers to well-organized systems. This paper highlights the new studentsadmission in State Universities (PTN), specifically about selfselection policies that have emerged later. Writing based on evaluation research with the choice of the Countenance Stake model that lasts from July 2017 to January 2018 takes place at the University of North Sumatra (USU) to obtain primary and secondary data from the USU Rector and Local Organizing Committee (PPL). Researchers also conducted in-depth interviews with students who were accepted through the UMBPT. This evaluation is expected to provide results that can be used as the references in the new student admission policy at PTN. 


\section{Stake's Countenance Evaluation Model}

Evaluation is a systematic effort to collect and process information that produces conclusions about the value, benefit, and performance of educational institutions or performance units from educational institutions or work units evaluated, to then use the results of the evaluation for making decision and planning process.

The Countenance Stake model is an analysis of the evaluation process that have a considerable impact on the field of evaluation research, implementation, programs and policies.

In conducting evaluation research, implementing a program or policy, Stake uses the concept of Countingency and Congruence. Each policy evaluation has two methods that are principle in processing evaluation data that are descriptive, namely determining possibilities among three phase (antecedents, transactions and outcomes) and determining the suitability of objectives and observations. Stake's evaluation model explains that evaluating or evaluating has the following steps: a) explain the program or policy, b) report information to interested parties, c) get and do judgment analysis, d) report back the results of the analysis. For using the evaluation model, Stake recommends that evaluation researchers apply two types of operations, which are descriptions andjudgment.

The use of the countenance evaluation model can provide the following benefits:1) The countenance model can provide a fairly clear description of the implementation of a program / policy from the initial context to the results obtained. 2) The countenance model also describes comprehensively in receiving information related to the implementation of a program / policy. 3) In giving consideration to standards, the countenance model not only measures the implementation of programs / policies according to planning, but also can know the achievement of predetermined standards. 4) With the consideration of groups or people who are qualified in their fields, researchers can find out about program drivers and program / policy barriers.

The principles and concepts above are the basis of consideration for researchers using the Stake evaluation model or countenance model compared to other models.

\section{UMBPT Policy at USU}

The independent PTN new student admission policy is one of the efforts to increase the number of people or high school graduates and equivalent to get the opportunity to study at PTN. So, based on the aspects of opportunity and needs, and their benefits, the government issues National Minister of Education Regulation and Minister of Research and Technology which states that in admission of new undergraduate programs and SNMPTN and SBMPTN, PTN new students can be accepted through the exam independently, at most $30 \%$ for each study program or faculty at PTN. SNMPTN and SBMPTN are selection paths conducted nationally, while the tests are independently carried out by each PTN independently. The Datasets of this study is accesable at https://osf.io/3dj7v/ in osf.

\section{Evaluation of the UMBPT Policy at USU}

\subsection{Antecedents Phase}

Evaluation of the Implementation of the New Student Admission Policy through the path of the Independent Screening Examination (UMBPT) at USU at the initial stage includes the basic foundation of policy making, the stages of policy making and also the clarity of the content of the policy. 
The explanation above was analyzed using the Stake's Countenence model congruence method.

Table 1. Congruence Analysis of Antecendents Phase Components

\begin{tabular}{|c|c|c|c|}
\hline & Description & & Judgement \\
\hline Intents & Observations & Standart & Decision \\
\hline $\begin{array}{l}\text { Minister of National } \\
\text { Education } \\
\text { Regulation Number } \\
34 \text { of } 2010\end{array}$ & $\begin{array}{l}\text { - Having a legal basis (policy) based } \\
\text { on: } \\
\text { - To provide greater opportunities for } \\
\text { high school graduates and a series of } \\
\text { students to study at state universities } \\
\text { specifically studying at USU. }\end{array}$ & $\begin{array}{l}\text { Adequacy: } \\
\text { Making the New Student } \\
\text { Admission Policy through } \\
\text { the USU's UMBPT,clearly } \\
\text { has sufficient reasons and } \\
\text { grounds. }\end{array}$ & $\begin{array}{l}\text { Decision: } \\
\text { UMBPT has legal basis } \\
\text { that is relevant and } \\
\text { legally valid based on } \\
\text { regulations. }\end{array}$ \\
\hline \multirow[t]{4}{*}{$\begin{array}{l}\text { The stages of } \\
\text { making a New } \\
\text { Student Admission } \\
\text { Policy through } \\
\text { UMBPT at USU }\end{array}$} & $\begin{array}{l}\text { Issue Identification: } \\
\text { - Identifying incoming issues through } \\
\text { the results of monitoring and } \\
\text { evaluation and in the form of } \\
\text { reports from the implementation of } \\
\text { UMBPT in previous years. } \\
\text { - Identifying the results of } \\
\text { discussions and meetings of the P- } \\
\text { SPMBN) }\end{array}$ & $\begin{array}{l}\text { Accuracy and Adequacy: } \\
\text { The identification of New } \\
\text { Student Admission Policy } \\
\text { issues through UMBPT at } \\
\text { USU uses appropriate } \\
\text { identification methods and } \\
\text { techniques and is supported } \\
\text { by fairly accurate } \\
\text { information. }\end{array}$ & $\begin{array}{l}\text { Identifying the } \\
\text { issuehas } \quad \text { used } \\
\text { appropriate methods } \\
\text { and techniques and is } \\
\text { supported by sufficient } \\
\text { data (information) }\end{array}$ \\
\hline & $\begin{array}{l}\text { Formation of Formulating Team: } \\
\text { In the stage of UMBPT Policy } \\
\text { Making at USU a formulation team } \\
\text { was formed nationally in P-SPMBN } \\
\text { along with the Chancellors of State } \\
\text { Universities who joined it as well as } \\
\text { the parties involved in the } \\
\text { implementation }\end{array}$ & $\begin{array}{l}\text { Responsiveness: Include } \\
\text { and involve relevant parties } \\
\text { who are competent in } \\
\text { formulating policy making } \\
\text { as a form of responsiveness } \\
\text { in drafting the New Student } \\
\text { Admission Policy through } \\
\text { UMBPTUSU }\end{array}$ & $\begin{array}{l}\text { The formation of a } \\
\text { drafting team has } \\
\text { followed the series and } \\
\text { involved various parties } \\
\text { / components that are } \\
\text { related and competent } \\
\text { in formulating policies }\end{array}$ \\
\hline & $\begin{array}{l}\text { Discuss from the zero draft New } \\
\text { Student Admission Policy through } \\
\text { USU's UMBPT: In this phase the } \\
\text { team formulates a policy draft } \\
\text { (commonly called a zero draft) and } \\
\text { discuss about it in the Chancellor's } \\
\text { forum to produce draft - } 1\end{array}$ & $\begin{array}{l}\text { Responsiveness: } \\
\text { Include and involve the } \\
\text { participation of USU and the } \\
\text { Public Components and PPL }\end{array}$ & $\begin{array}{l}\text { The zero draft has been } \\
\text { discussed and discussed } \\
\text { by including the } \\
\text { participation of the } \\
\text { public component, the } \\
\text { Chancellor and PPL } \\
\text { from USU. }\end{array}$ \\
\hline & $\begin{array}{l}\text { Legislation Process: } \\
\text { In the process of legislation / } \\
\text { endorsement gave birth to the } \\
\text { formulation of New Student } \\
\text { Admissions Policy through UMBPT } \\
\text { in the form of Minister of Research, } \\
\text { Technology and Higher Education } \\
\text { Regulation number } 2 \text { of } 2015\end{array}$ & $\begin{array}{l}\text { Efficiency:Effective and } \\
\text { efficient legislative } \\
\text { processes produce policy } \\
\text { formulations in the form of } \\
\text { Ministerial Regulations }\end{array}$ & $\begin{array}{l}\text { The process of } \\
\text { legalizing the UMBPT } \\
\text { / Mandiri Examination } \\
\text { policy in PTN is on } \\
\text { target and produces } \\
\text { formulas in the form of } \\
\text { Permen. }\end{array}$ \\
\hline $\begin{array}{l}\text { Clarity of Content } \\
\text { Policy }\end{array}$ & $\begin{array}{l}\text { Content Policy: Through the } \\
\text { evaluation results, it can be seen that } \\
\text { the New Student Admission Policy } \\
\text { through the UMBPT already has } \\
\text { clear goals and objectives. }\end{array}$ & $\begin{array}{l}\text { Accuracy and Adequacy: } \\
\text { The UMBPT already has } \\
\text { appropriate and appropriate } \\
\text { content and is strategic, } \\
\text { useful according to the } \\
\text { objectives to be achieved. }\end{array}$ & $\begin{array}{l}\text { Content } \\
\text { UMBPTappropriate } \\
\text { and appropriate to the } \\
\text { strategic problems and } \\
\text { objectives to be } \\
\text { achieved and easy to } \\
\text { understand. }\end{array}$ \\
\hline
\end{tabular}

\subsection{Transaction Phase}

There are some variables in the transaction phase in this study are: preparation and planning, provision of facilities and infrastructure, coordination and organization, implementation, supervision, evaluation, 
up to the costs of implementation and supporting and inhibiting factors for the implementation of new student admission policies through the UMBP at USU. The evaluation of the new student admission policy through the UMBPT USU based on the analysis of Robert's E. Stake countenance model, is presented in the following table:

Table 2. Congruence Analysis of Robert's E. Stake Countenence Model Transactions Phase component.

\begin{tabular}{|c|c|c|c|}
\hline \multicolumn{2}{|r|}{ Description } & \multicolumn{2}{|c|}{ Judgement } \\
\hline Intents & Observations & Standart & Decision \\
\hline $\begin{array}{l}\text { Preparation } \\
\text { and planning }\end{array}$ & $\begin{array}{l}\text { UMBPT had made preparations } \\
\text { and plans before the UMBPT } \\
\text { was carried out at USU's PPL. } \\
\text { The central tasks and authority } \\
\text { of the PPL core team are in } \\
\text { accordance with the UMBPT } \\
\text { Handbook and Chancellor's } \\
\text { Decree }\end{array}$ & $\begin{array}{l}\text { Accuracy and } \\
\text { Adequacy: } \\
\text { Make and plan } \\
\text { accordingly and prepare } \\
\text { according to the USU } \\
\text { Local Organizing } \\
\text { Committee (PPL) } \\
\text { Guidelines }\end{array}$ & $\begin{array}{l}\text { The Organizers of the } \\
\text { UMBPT have made } \\
\text { appropriate plans and } \\
\text { made appropriate } \\
\text { preparations as stipulated } \\
\text { by PPL USU }\end{array}$ \\
\hline $\begin{array}{l}\text { Provision of } \\
\text { facilities and } \\
\text { infrastructure }\end{array}$ & $\begin{array}{l}\text { Based on the results of the study } \\
\text { it was found that the provision of } \\
\text { facilities and infrastructure } \\
\text { needed in the implementation of } \\
\text { the USU's UMBPT at USU PPL. }\end{array}$ & $\begin{array}{l}\text { Accuracy and } \\
\text { Adequacy: } \\
\text { Provision of facilities } \\
\text { and infrastructure is } \\
\text { no problem }\end{array}$ & $\begin{array}{l}\text { Facilities and } \\
\text { infrastructure for } \\
\text { implementing UMBPT } \\
\text { USU PPL as needed }\end{array}$ \\
\hline $\begin{array}{l}\text { Coordination / } \\
\text { Organizing }\end{array}$ & $\begin{array}{l}\text { Information was obtained that } \\
\text { coordinating and organizing } \\
\text { human resources through USU's } \\
\text { PPL was coordinated and well } \\
\text { organized according to their } \\
\text { respective duties. The } \\
\text { relationship between fields and } \\
\text { duties and authority in USU's } \\
\text { PPL Team can function in } \\
\text { accordance with USU's PPL } \\
\text { guidelines }\end{array}$ & $\begin{array}{l}\text { Responsiveness and } \\
\text { Accuracy: Involving } \\
\text { all PPL, Deans, } \\
\text { Lecturers and } \\
\text { Employees. Organizing } \\
\text { / coordinating HR } \\
\text { properly and synergy }\end{array}$ & $\begin{array}{l}\text { Coordination of human } \\
\text { resources by USU PPL } \\
\text { starting from PPL to } \\
\text { locations and well } \\
\text { coordinated } \\
\text { examination rooms }\end{array}$ \\
\hline Implementation & $\begin{array}{l}\text { Implementation of the UMBPT } \\
\text { at USU is in accordance with } \\
\text { USU's PPL guideline procedures }\end{array}$ & $\begin{array}{l}\text { Conformity: The } \\
\text { UMBPT in accordance } \\
\text { with the Minister of } \\
\text { Education and Culture, } \\
\text { Permenristekdikti, the } \\
\text { Rector's Decree and } \\
\text { USU's PPL guidelines }\end{array}$ & $\begin{array}{l}\text { PPL UMBPT took place } \\
\text { according to the } \\
\text { procedures regulated by } \\
\text { the Minister of National } \\
\text { Education, } \\
\text { Permenristekdikti, PPL / } \\
\text { Outlet Guidelines and } \\
\text { USU Chancellor's Decree }\end{array}$ \\
\hline Supervision & $\begin{array}{l}\text { The results of the study stated } \\
\text { that } 100 \% \text { supervision by the } \\
\text { implementation of the USU PPL } \\
\text { supervision took place well and } \\
\text { strictly }\end{array}$ & $\begin{array}{l}\text { Responsiveness and } \\
\text { Accuracy: Responsive } \\
\text { supervision carried out } \\
\text { with the right } \\
\text { procedures. } \\
\end{array}$ & $\begin{array}{l}\text { Supervision in the } \\
\text { implementation of the } \\
\text { UMBPT according to the } \\
\text { rules of USU's } \\
\text { Chancellor's Decree }\end{array}$ \\
\hline Monitoring & $\begin{array}{l}\text { The results of the research and } \\
\text { interviews with the Chairperson } \\
\text { of the PPL, } 5 \text { Deans, and } 11 \text { PPL } \\
\text { members showed that } \\
\text { monitoring was carried out } \\
100 \% \text { when the UMBPT took } \\
\text { place }\end{array}$ & $\begin{array}{l}\text { Responsiveness and } \\
\text { accuracy:Responsive } \\
\text { monitoring is carried } \\
\text { out by PPL and deans } \\
\text { in their respective } \\
\text { faculties }\end{array}$ & $\begin{array}{l}\text { Monitoring on the } \\
\text { ongoing UMBPT is } \\
\text { carried out appropriately } \\
\text { by the PPL. }\end{array}$ \\
\hline Evaluation & The results of the open interview & Responsiveness and & USU PPL does not or has \\
\hline
\end{tabular}




\begin{tabular}{|l|l|l|l|}
\hline & $\begin{array}{l}\text { study with the Chairperson of } \\
\text { the PPL, Deputy Chancellor, 11 } \\
\text { PPL Core Teams and 5 Deans } \\
\text { said that they had never taken a } \\
\text { serious evaluation }\end{array}$ & $\begin{array}{l}\text { accuracy: The actor ive } \\
\text { evaluation of the } \\
\text { implementation of the } \\
\text { UMBPT was not } \\
\text { conducted }\end{array}$ & $\begin{array}{l}\text { never evaluated the } \\
\text { results of monitoring }\end{array}$ \\
\hline $\begin{array}{l}\text { USU's UMBPT } \\
\text { / Independent } \\
\text { Exam costs }\end{array}$ & $\begin{array}{l}\text { Based on research interviews } \\
\text { with USU PPL, deans, and } \\
\text { independent students and their } \\
\text { parents said that the costs of } \\
\text { administering USU's UMBPT } \\
\text { were all charged to participants }\end{array}$ & $\begin{array}{l}\text { Adequacy and Equity: } \\
\text { The absence of fees } \\
\text { from the organizers was } \\
\text { all borne by USU's } \\
\text { UMBPTparticipants }\end{array}$ & $\begin{array}{l}\text { Does not reflect justice } \\
\text { between participants and } \\
\text { organizers }\end{array}$ \\
\hline $\begin{array}{l}\text { Supporting and } \\
\text { Inhibiting }\end{array}$ & $\begin{array}{l}\text { It was found that USU PPL } \\
\text { respondents stated that the } \\
\text { implementation of the UMBPT } \\
\text { USU supporting actors was far } \\
\text { greater than the inhibiting } \\
\text { factors, but the PPL inhibiting } \\
\text { factors could be overcome by } \\
\text { good cooperation. }\end{array}$ & $\begin{array}{l}\text { Efficiency and } \\
\text { Adequacy: That } \\
\text { supporting actors are } \\
\text { very effective in } \\
\text { encouraging the } \\
\text { successful } \\
\text { implementation of }\end{array}$ & $\begin{array}{l}\text { Supporting factors } \\
\text { efficiently support and } \\
\text { encourage the successful } \\
\text { implementation of } \\
\text { UMBPT in USU's PPL }\end{array}$ \\
\hline
\end{tabular}

\subsection{Outcome Phase}

In evaluating the outcome phase related to the new student admission policy through USU's UMBPT / Independent Examination, researchers conducted outcome evaluations within the limits of student results received through examinations independently in 7 faculties at USU from 2010 to 2016, namely: Faculty of Medicine, Faculty of Law, Faculty of Economics and Business, Acceptance of students from the Faculty of Dentistry, Faculty of Cultural Sciences, Faculty of Mathematics and Natural Sciences, and Faculties.

Table 3. Congruence Analysis of Robert's E. Stake Countenence Model Outcomes Phase component.

\begin{tabular}{|c|c|c|c|}
\hline \multicolumn{2}{|c|}{ Description } & \multicolumn{2}{|c|}{ Penilaian (Judgement) } \\
\hline Intents & Observations & Standart & Decision \\
\hline $\begin{array}{l}\text { Balancing the } \\
\text { composition of students } \\
\text { who get subsidies with } \\
\text { students who finance } \\
\text { independently }\end{array}$ & $\begin{array}{l}\text { In the seven student } \\
\text { faculties through the } \\
\text { SNMPTN and SBMPTN } \\
\text { pathways the percentage } \\
\text { was greater than students } \\
\text { who were accepted through } \\
\text { the UMBPT }\end{array}$ & $\begin{array}{l}\text { Accuracy and } \\
\text { suitability: Make and } \\
\text { plan accordingly and } \\
\text { prepare according to the } \\
\text { USU Local Organizing } \\
\text { Committee (PPL) } \\
\text { Guidelines }\end{array}$ & $\begin{array}{l}\text { The goal of achieving } \\
\text { balance is appropriate }\end{array}$ \\
\hline $\begin{array}{l}\text { Increased Facilities and } \\
\text { Infrastructure at USU }\end{array}$ & $\begin{array}{l}\text { There is an increase in } \\
\text { facilities and infrastructure } \\
\text { financed from funds } \\
\text { obtained from the Mandiri } \\
\text { Examination policy }\end{array}$ & $\begin{array}{l}\text { Suitability and } \\
\text { Adequacy: } \\
\text { Provision of adequate } \\
\text { facilities and } \\
\text { infrastructure }\end{array}$ & $\begin{array}{l}\text { The purpose of improving } \\
\text { the quality of education } \\
\text { services is appropriate }\end{array}$ \\
\hline
\end{tabular}




\section{Conclusion}

There are several conclusion that have been got for this studi from evaluating UMBPT at USU using the Countenence Stake model:

1. Independent examination policy for the new students admission at USU in accordance with needs,interests and benefits.

2. Implementation of PTN's new student admission policy in USU PPL based on criteria for accuracy,adequacy, and responsiveness has been carried out through the process of preparation and planning, provision of facilities and infrastructure, coordination of human resources, supervision and evaluation.

\section{References}

[1] Anderson, James E., Public Policy Making, Second Edition, New York: Praeger Publisher (1978)

[2] Bargh. Chatherine,et.al, Governing Universities Changing the Culture?, USA (1996)

[3] Coombs, Phillip H., The World Educational Crisis: A Systems Analysis, New York : Oxford University Press (1968)

[4] William N., Public Policy Analysis: An Introduction, Second Edition, New Jersey: Pearson Prentice Hall (2004)

[5] Kerr, Clark. The Uses of University, California: Torch Book The Academy Library (1963)

[6] Stufflebeam, Daniel L. dan Anthony, Evaluation Theory, Models and Aplication, San Fransisco: Jossey Bass (2007)

[7] Stake, Robert E., Program Evaluation, Particulary Responsive Evaluation, diedit oleh Daniel L. Stufflebeam, George F. Madaus and Thomas Kellaghan, Evaluation Models, Vewpoints on Educational and Human Services Evaluation, Second Edition, New York, Boston, Dordrect, London, Moscow: Kluwer Akacemic Publisher (2000)

[8] Stake, Robert E., The Art Of Case Study Research, diedit oleh Astrid Viding, London: Sage Publications Inc (1995)

[9] Suandi S. Datasets University Management Interview Scripts. OSF, (2019) https://osf.io/3dj7v/ 